\title{
STUDY OF IN-SITU AND LABORATORY HYDRAULIC CONDUCTIVITY OF CONTAMINATED SOIL WITH OILY WASTEWATER
}

\author{
FERZAND KAMAL AHMED MEDHAT ${ }^{1 *}$ and Yousif ISMAEL MAWLOOD ${ }^{* *}$ \\ "Erbil Polytechnic University-Erbil, Kurdistan Region-Iraq \\ ${ }^{* *}$ College of Engineering, University of Salahaddin/Erbil, Kurdistan Region-Iraq
}

(Accepted for Publication: December 8, 2020)

\begin{abstract}
This study aims to investigate the effect of contaminated soil samples with oily wastewater which were taken from Kawergosk refinery ( $20 \mathrm{~km}$ west of Erbil city). Laboratory constant head permeability tests on contaminated soil samples with oily wastewater have been conducted. Also, One-Dimensional (1-D) and Three-Dimensional (3-D) in-situ permeability tests were performed. A noticeable decrease in the values of hydraulic conductivity coefficient $(k)$ have been observed for Contaminated Soil Samples comparing with uncontaminated samples. Results of hydraulic conductivity coefficient obtained from one dimensional consolidation tests were increased with increasing of applied stresses. The results of field permeability tests revealed that the surrounding lands of Kawergosk refinery lies within the range of semi-permeable area for urban development while the majority part of the area lies within the range of moderate area for agricultural and conservation purposes.
\end{abstract}

KEYWORDS: Soil contamination; Permeability; Oily wastewater; soil pits; consolidation

\section{INTRODUCTION}

$\mathbf{T}$ The increase of the industrial wastes, especially in the petroleum industry leads to many environmental pollution problems such as air, water and soil. Regarding the soil contamination, a various geotechnical characteristic change has been observed in the surrounding areas of oilfields and refineries. The main source of oil pollution is from the oil spill leakage in the oilfields and during transportation through damaged and old pipelines in the refinery. The source of the polluted oil is somehow difference if it comes from the transportation of oil products by trucks during accidents and leaks from the truck itself as this traditional way is widely used to reach the end-users. On the other hand, the riskiest source of oil pollution in the refineries is in the untreated wastewater (Oily wastewater), which will be released from some refineries to the nearby area; this type of pollution has been widely observed in this investigation. Before this study, the effect of Kawergosk refinery wastewater on surrounding water resources has been studied.( Aziz and Fakhrey (2016), in their study about the effect of Kawergosk oil refinery on surrounding water resource they have observed high pollutants in the refinery wastewater treatment plant.

The degree of soil contamination depends on Oily wastewater properties, (Fine et al, 1997). The influence of the various oil products on the geotechnical properties of soils have been studied by many researchers, (Abdul-Resol, 1999; Al-Sanad \& Ismael, 1997; Karkush \&

ferzand.medhat@epu.edu.krd; yousif.mawlood@su.edu.krd

${ }^{1}$ Corresponding author:Erbil Polytechnic University- Erbil, Kurdistan Region, Iraq. 
Kareem, 2017; Khamehchiyan, Charkhabi, \& Tajik, 2007).

In general, adding oily wastewater to the soil induces a small reduction in permeability due to the properties of the additives, because the first contact of the oil will be with the soil particles and decreases void ratio which intern reduces hydraulic conductivity, (Akinwumi, Diwa, Obianigwe, \& Research, 2014; Rahman, Hamzah, Taha, Ithnain, \& Ahmad, 2010; Ur-Rehman, Abduljauwad, \& Akram, 2007), found that $\mathrm{k}$ values obtained from consolidation tests for laboratory contaminated soil samples varied with variation of applied stresses, this results have been noticed already by other researcher (Khamehchiyan, Hossein Charkhabi, \& Tajik, 2007; Shah, Shroff, Patel, Tiwari, \& Ramakrishnan, 2003).

\section{MATERIALS AND METHODS}

The polluted areas around the refinery (especially the west side, where most villages exist there) are shown in Figure (1). The contaminated soil samples with oily wastewater were taken from the outlet of the Kawergosk refinery units that contain more than $80 \%$ water.

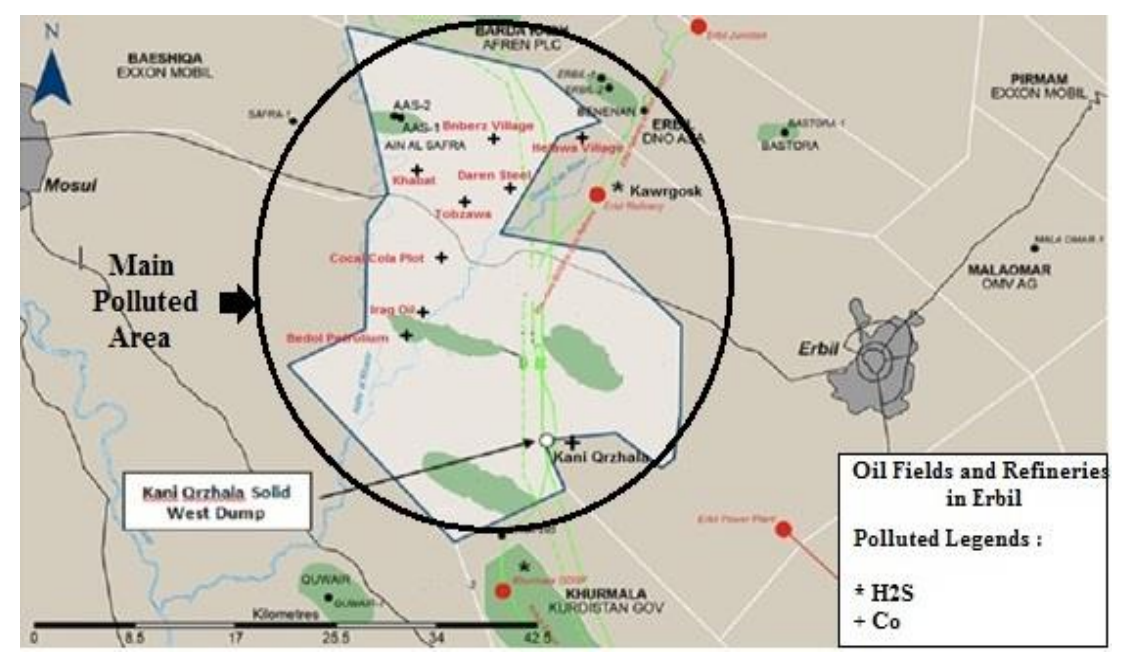

Fig. (1): polluted map in Kawergosk area

Which the physical and compressibility characteristics were determined and given in Table (1) while the specifications of oily wastewater are given in Table (2). The experimental works in this study includes;

*Field permeability tests for contaminated soil with oily wastewater

*Laboratory permeability tests for contaminated soils using, Falling head method.
*One dimensional consolidation test method.

In-situ permeability tests were carried out in two pits, $30 \mathrm{~cm}$ diameter and $50 \mathrm{~cm}$ depth, inside one of these pits a steel pipe has been fixed for measuring one-dimensional penetration (diffusion), while the other one was used for measuring a three-dimensional penetration of oily wastewater.

ferzand.medhat@epu.edu.krd; yousif.mawlood@su.edu.krd 
Table (1): The characteristics of investigated soil sample

\begin{tabular}{lll}
\hline Properties & Soil Sample \\
\hline Field water content $(\mathrm{m}) \%$ & 5.6 \\
\hline Specific Gravity (Gs) & & 2.7 \\
\hline \multirow{3}{*}{ Atterberg limits } & Liquid Limit (LL), \% & 37.8 \\
\cline { 2 - 3 } & Plastic Limit (PL), \% & 14.7 \\
\cline { 2 - 3 } & Plasticity Index (PI), \% & 23.1 \\
\hline \multirow{3}{*}{ Particle size distribution } & Gravel, \% & 4.0 \\
\cline { 2 - 3 } & Sand, \% & 26 \\
\cline { 2 - 3 } & Silt, \% & 24 \\
\cline { 2 - 3 } & Clay, \% & 46 \\
\hline Unified Soil Classification & Sandy lean clay (CL) \\
\hline Field density $\left(\rho_{t}\right)$ gm/cm ${ }^{3}$ & 1.40 \\
\hline
\end{tabular}

Table (2): The physical properties of oily wastewater

\begin{tabular}{|c|c|c|c|c|c|}
\hline Test & Unit & In-let & $\begin{array}{c}\text { FAO } \\
\text { 1992standards } \\
\text { for irrigation }\end{array}$ & $\begin{array}{c}\text { Turkish } \\
\text { standards for } \\
\text { irrigation }\end{array}$ & $\begin{array}{l}\text { WHO 2011, } \\
\text { standards for } \\
\text { drinking water }\end{array}$ \\
\hline ECw & $\mu \mathrm{s} / \mathrm{cm}$ & 1745 & $700-3000$ & $700-3000$ & 1000 \\
\hline TDS & $\mathrm{ppm}$ & 872.5 & $450-2000$ & $500-2000$ & 500 \\
\hline Calcium (Ca) & $\mathrm{ppm}$ & 5 & 20 & 20 & 200 \\
\hline $\begin{array}{l}\text { Magnesium } \\
\quad(\mathrm{Mg})\end{array}$ & $\mathrm{ppm}$ & 3.13 & 60 & 30 & 30 \\
\hline Sodium (Na) & $\mathrm{ppm}$ & 14.11 & 900 & 900 & 200 \\
\hline Chloride $(\mathrm{Cl})$ & ppm & 0.33 & $4-10$ & $4-10$ & 5 \\
\hline Iron $(\mathrm{Fe})$ & ppm & 2.3 & 5 & $0.1-1.5$ & 0.3 \\
\hline Nitrate $\left(\mathrm{NO}_{3}\right)$ & ppm & 26 & $5-30$ & $10-30$ & 50 \\
\hline $\mathrm{pH}$ & & 9.4 & $6.5-8.4$ & $7-8$ & $6.5-9.5$ \\
\hline Oil & $\%$ & 15 & & & \\
\hline Water Content \% & $\%$ & 85 & & & \\
\hline
\end{tabular}

The oily wastewater has been spilled into the two pits at the same time and the rate of penetration (diffusion) were recorded until the disappearance of the oily wastewater, then the $k$ values were determined (ASTM D6391 -2011). Figure (2) shows one- and three-dimensional diffusion rates for examined soil.

ferzand.medhat@epu.edu.krd; yousif.mawlood@su.edu.krd 


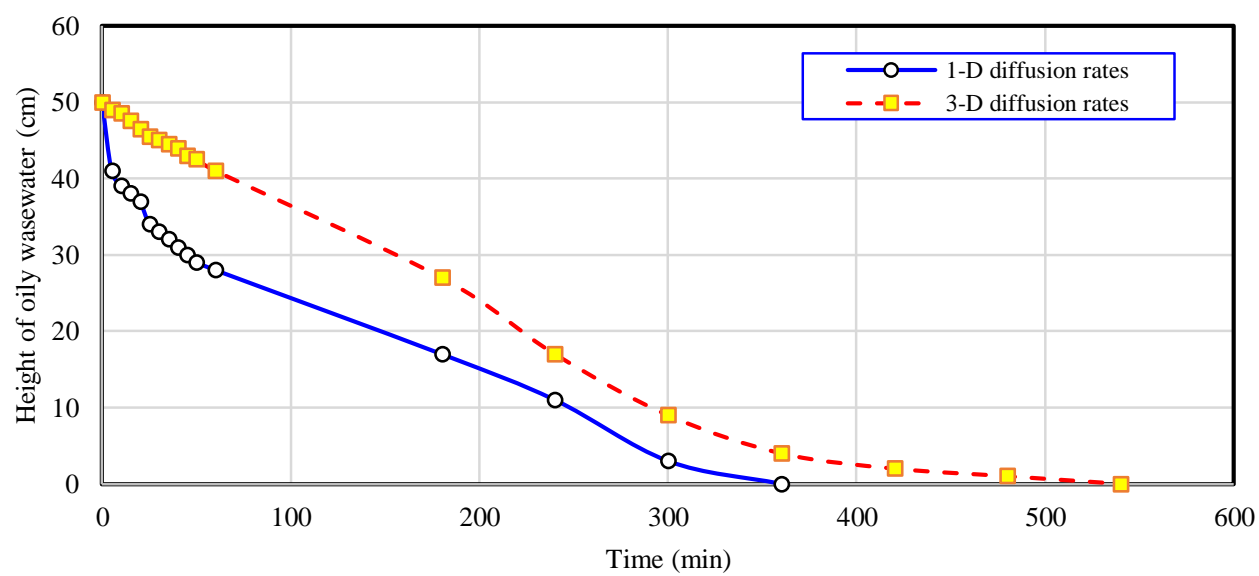

Fig. (2): One- and three-dimension diffusion rates

Results of $\mathrm{k}$ values have been determined, (ASTM D6391- 2011), using this Equation (1); $\mathrm{k}=\left[(\mathrm{D} / 2) * \ln \left(\mathrm{h}_{1} / \mathrm{h}_{2}\right)\right] / 2\left(\mathrm{t}_{2}-\mathrm{t}_{1}\right)$

Were; $(\mathrm{D} / 2)$ is the radius of the hole in meters. In refers to the national logarithm, $\left(\mathrm{h}_{1}\right.$ and $\left.\mathrm{h}_{2}\right)$ are the two consecutive depths of oily wastewater in meters. ( $\left.\mathrm{t}_{2}-\mathrm{t}_{1}\right)$ expresses the time interval between two consecutive measurements in seconds. The value of $k$ is in $\mathrm{m} / \mathrm{sec}$ (neglecting the effect of viscosity of the oily waste water, because it contains less than $15 \%$ waste oil). Test results are shown in Table (3).

Table (3): The 3D field permeability test results (Diameter of hole $=40 \mathrm{~cm}$ )

\begin{tabular}{cccc}
\hline $\begin{array}{c}\text { Elapsed time } \\
(\mathbf{m i n})\end{array}$ & $\begin{array}{c}\text { Height of wastewater } \\
\text { in the Hole } \mathbf{( H )} \\
(\mathbf{c m})\end{array}$ & $\begin{array}{c}\text { Change in Height } \\
\text { with time }(\Delta \mathbf{H}) \\
(\mathbf{c m})\end{array}$ & $\begin{array}{c}\mathbf{k} \\
(\mathbf{m} / \mathbf{s e c})\end{array}$ \\
\hline 0 & 50 & 0 & $6.73424 \mathrm{E}-06$ \\
\hline 300 & 49 & 1 & $3.41883 \mathrm{E}-06$ \\
\hline 600 & 48.5 & 1.5 & $6.9447 \mathrm{E}-06$ \\
\hline 900 & 47.5 & 2.5 & $7.09247 \mathrm{E} .06$ \\
\hline 1200 & 46.5 & 3.5 & $7.24666 \mathrm{E}-06$ \\
\hline 1500 & 45.5 & 4.5 & $3.68328 \mathrm{E}-06$ \\
\hline 1800 & 45 & 5 & $3.72443 \mathrm{E}-06$ \\
\hline 2100 & 44.5 & 5.5 & $3.76652 \mathrm{E}-06$ \\
\hline 2400 & 44 & 6 & $7.66317 \mathrm{E}-06$ \\
\hline 2700 & 43 & 7 & $3.89868 \mathrm{E}-06$ \\
\hline 3000 & 42.5 & 7.5 & $5.80188 \mathrm{E}-06$ \\
\hline 3600 & 41 & 9 & $5.80188 \mathrm{E}-06$ \\
\hline
\end{tabular}

ferzand.medhat@epu.edu.krd; yousif.mawlood@su.edu.krd ${ }^{1}$ Corresponding author:Erbil Polytechnic University- Erbil, Kurdistan Region, Iraq. 


\begin{tabular}{llll}
\hline 10800 & 27 & 23 & $1.28507 \mathrm{E}-05$ \\
\hline 14400 & 17 & 33 & $1.76664 \mathrm{E}-05$ \\
\hline 18000 & 9 & 41 & $2.25258 \mathrm{E}-05$ \\
\hline 21600 & 4 & 46 & $1.92541 \mathrm{E}-05$ \\
\hline 25200 & 2 & 48 & $1.92541 \mathrm{E}-05$ \\
\hline 28800 & 1 & 49 & $1.92541 \mathrm{E}-05$ \\
\hline 32400 & 0 & 50 & $1.92541 \mathrm{E}-05$ \\
\hline
\end{tabular}

Note: $k$ value for the field test is $1.92541 \mathrm{E}-05 \mathrm{~m} / \mathrm{sec}$.

At the end of the tests, the samples were taken from the base and sides of the two holes for examining laboratory falling head permeability tests. Regarding the laboratory tests for the determination of $k$,values, a contaminated soil samples have been investigated in the laboratory, for conducting permeability tests (falling head method). The remolded soil sample was prepared in the lab, having the same field density inside the permeability mold. Oily wastewater has been used instead of water for the test; this process is similar to the one that had been conducted in the field.

Laboratory permeability tests were carried out using falling head method (ASTM D 5084-03), in this test the oily wastewater was used instead of water on remolded soil samples by duplicating initial water content and field density for comparison purposes of field and laboratory tests. Another set of laboratory falling head permeability tests were carried out on contaminated soil samples with four different percentages $(5 \%, 10 \%, 15 \%$ and $20 \%)$ of oily wastewater, in order to investigate the effect of pollution percentage on the $k$ value and also to be used as a base for estimating the degree of contamination of the soils in the field.

Finally, one-dimensional consolidation tests have been carried out (ASTM D 2435) on laboratory polluted soil samples with oily wastewater for the purpose of comparing of the $k$ values with field permeability tests, and to what extend the small-scale laboratory tests represent the field performance of contaminated soil with oily wastewater, this is important for the surrounding areas of the refineries in which they are usually subjected to oily wastewater pollutions.

\section{RESULTS AND DISCUSSIONS}

Refer to Table (1), the physical characteristics and Table (2), the oily wastewater properties, the contaminated soil samples with oily wastewater have been investigated regarding its penetration (diffusion) through sub soils. From the results obtained in the diffusion rate curves, Figure (1) and $k$ values obtained from Table (3), it can be observed that higher values are seen for 3-D penetration because the oily wastewater spreads in all directions and took less time until the oily wastewater disappear in the pits. because of the 3-D field diffusion which is most likely are occurred on the polluted lands, determination of field permeability or (field diffusion) becomes necessary.

Regarding the results of in-situ permeability test values, Table (3) for field contaminated soil samples with oily wastewater, the results of 3-D filed permeability $(1.92541 \mathrm{E}-05 \mathrm{~m} / \mathrm{s})$ shows that the field clay soil is within the range of low permeable for civil engineering purposes (ASTM, D 6391, 2011; Ishibashi \& Harazika, 2015), and within the range of moderate for agricultural and conservation purposes, the effect of oily wastewater on the contamination of existing soil would be seen in long and medium-term periods.

The word diffusion could be better to use

ferzand.medhat@epu.edu.krd; yousif.mawlood@su.edu.krd

${ }^{1}$ Corresponding author:Erbil Polytechnic University- Erbil, Kurdistan Region, Iraq. 
instead of permeability, due to the Viscosity effect, although this factor has a small effect, because the refineries oily wastewater contained more than $80 \%$ of water. The permeability result obtained was $(0.272 \quad \mathrm{E}-3 \quad \mathrm{~cm} / \mathrm{sec}$ $=0.0063 \mathrm{E}-5 \mathrm{~m} /$ year $)$. Details of the test results are shown in Table (4).

Table (4): Laboratory permeability test results for field

\begin{tabular}{|c|c|c|c|}
\hline $\begin{array}{l}\Delta \mathrm{H} \\
(\mathrm{cm})\end{array}$ & $\begin{array}{l}\text { Time } \\
\text { (sec) }\end{array}$ & $\begin{array}{c}\mathrm{k}\left(\times 10^{-3}\right) \\
\mathrm{cm} / \mathrm{sec}\end{array}$ & $\begin{array}{c}\text { Modified } k \text { for } 19 c^{\circ} \\
\mathrm{cm} / \mathrm{sec}\end{array}$ \\
\hline 23 & 24.56 & 0.2498 & 0.2374 \\
\hline 26 & 13.57 & 0.1427 & 0.1355 \\
\hline 32 & 27.65 & 0.5139 & 0.4882 \\
\hline 33 & 53.5 & 1.2615 & 1.1984 \\
\hline 52.5 & 20.66 & 0.6372 & 0.6053 \\
\hline 31 & 28.44 & 1.227 & 1.1656 \\
\hline 24.5 & 44.65 & 1.948 & 1.8506 \\
\hline 30 & 44.63 & 2.3249 & 2.2086 \\
\hline 22 & 18.43 & 1.3363 & 1.2694 \\
\hline 36 & 21.78 & 0.7315 & 0.6949 \\
\hline 29 & 14.22 & 0.2566 & 0.2437 \\
\hline 34 & 46.57 & 1.864 & 1.7708 \\
\hline 24 & 17.25 & 1.0143 & 0.9635 \\
\hline 45 & 27.75 & 0.431 & 0.4095 \\
\hline \multicolumn{4}{|c|}{$\begin{array}{l}\text { Modified Value of } k=0.272 \times 10^{-3} \mathrm{~cm} / \mathrm{sec} \text {, } \\
\text { Average value of } k=0.285 \times 10^{-3} \mathrm{~cm} / \mathrm{sec}\end{array}$} \\
\hline
\end{tabular}

Another method for preparing a contaminated soil samples have been used for determining $k$ values, by contaminating the samples with various percentages of oily wastewater $(5 \%$, $10 \%, 15 \%$ and $20 \%$ ), then conducting a falling head permeability method for determining $k$ values. For comparison purpose with the other values of $k$, the results are shown in Table (5). The results obtained from the Table, it can be noted that $k$ values decreases with increase of the percentage of the contamination, this phenomenon happened also for field contaminated samples, this is because of the fact that the oil wastewater will enter the voids between the soil particles and hence reduces the void ratio which intern reduces the hydraulic conductivity. According to the values obtained in the Table (6), that shows a comparison between $k$ value results obtained from consolidation test for uncontaminated soil samples for both laboratory and field samples. From the Table it can be noted that the laboratory results decreased by $15 \%$, this could be because of the test procedure. A comparison between the results of $k$ for a laboratory contaminated soil samples with oily wastewater and the field test shows that the contamination was within the range of $10 \%$.

Table (5): Falling head method $\mathrm{k}$ values for laboratory contaminated soil samples

\begin{tabular}{lccccc}
\hline Percentage of contamination & $\mathbf{0} \%$ & $5 \%$ & $10 \%$ & $15 \%$ & $20 \%$ \\
\hline$k\left(\times 10^{-6}\right)$ in (m/year) & 2.0659 & 0.951 & 0.643 & 0.412 & 0.348 \\
\hline
\end{tabular}


Table (6): $\boldsymbol{k}$ values for uncontaminated and contaminated soil samples

\begin{tabular}{lc}
\hline Falling head permeability tests for & $\mathbf{k}\left(\times \mathbf{1 0 ^ { - 6 }}\right)$ ( $\mathbf{m} /$ year $)$ \\
\hline Uncontaminated soil sample & 2 \\
\hline Laboratory contaminated soil sample & 0.08 \\
\hline Field contaminated sample & 0.6 \\
\hline
\end{tabular}

A serial of 1-D laboratory consolidation tests and field permeability for contaminated soil samples have been carried out for determining $k$ values and comparing the results with the other results obtained before. Results of laboratory contaminated soil samples are illustrated in Figure (3), it can be observed that $k$ values decreases with increasing degree of contamination, for all applied stresses especially for highest one in which the significant increase were ( 0.002) for all contaminated percentages .In general, adding oily wastewater to the soil induces a small reduction in permeability $(k)$, due to the properties of oily wastewater mixture, because the first contact of the oil will be with the soil particles and decreases the volume of voids. Our results agree with the investigations of, Rahman et al. (2010) also agrees with the work of Akinwumi et al. (2014)

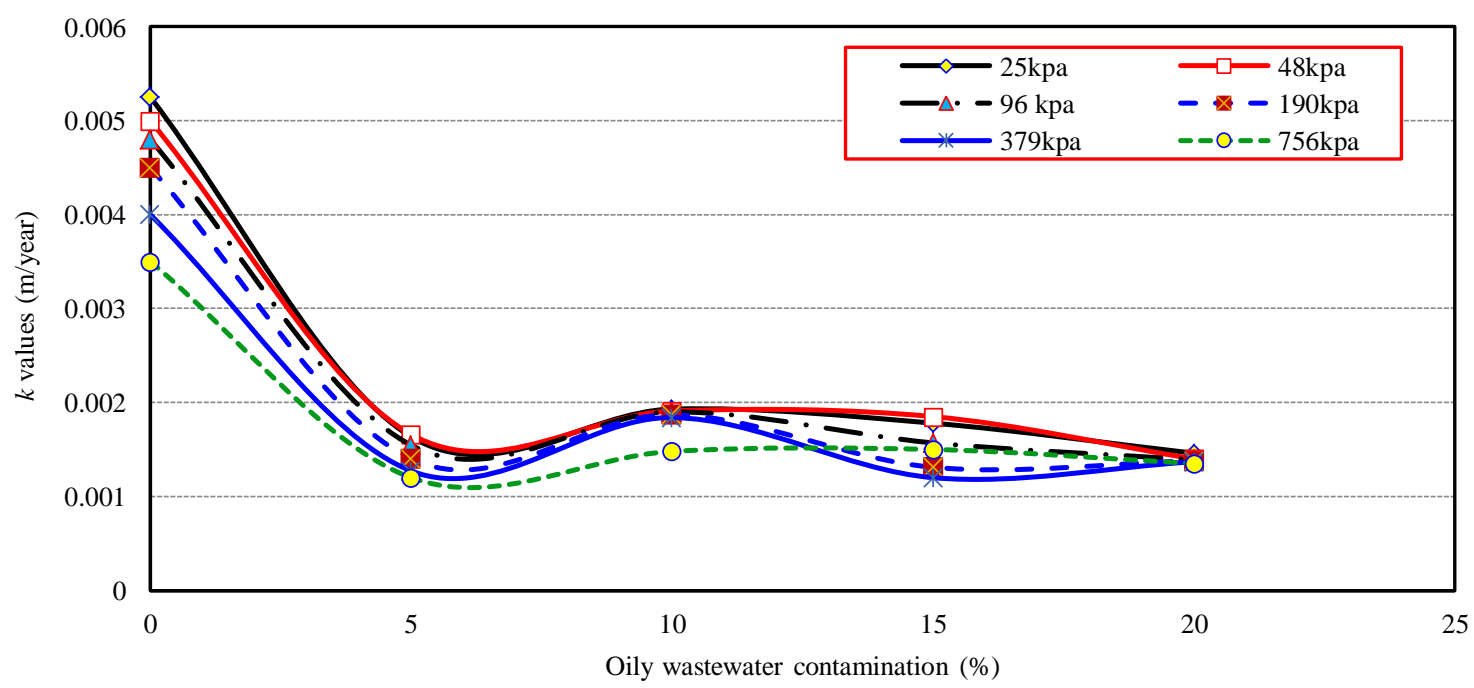

Fig (3): Effect of surcharge pressure on $\boldsymbol{k}$ values for different percentage of oily wastewater contamination by

Odometer test.

Results of $k$ obtained from consolidation test for field contaminated samples (1-D and 3-D diffusion rates) and comparison between their $k$ values with $k$ values from the laboratory consolidation tests are given in Table (7). The Tables illustrates that the $k$ value decreases for both field and laboratory contaminated soil samples obtained from field permeability and consolidation tests respectively, especially for high-applied stresses. The reason for that is, because the voids were partially filled with oil which at the end rejects the movement of the fluid. Similar results were obtained by other researchers, (Akinwumi et al., 2014; Ur-Rehman et al., 2007).

ferzand.medhat@epu.edu.krd; yousif.mawlood@su.edu.krd

${ }^{1}$ Corresponding author:Erbil Polytechnic University- Erbil, Kurdistan Region, Iraq. 
Table (7): Comparison between $(\boldsymbol{k})$ values obtained from consolidation test of field and laboratory contaminated soil samples

\begin{tabular}{ccccccccc}
\hline $\begin{array}{c}\text { Stresses } \\
(\mathbf{k P a})\end{array}$ & \multicolumn{2}{c}{$\begin{array}{c}\boldsymbol{k} \text { values for filed Permeability samples } \\
\text { (m/year) }\end{array}$} & & \multicolumn{3}{c}{$\boldsymbol{k}$ values for contaminated soil samples for consolidation test } \\
& 1-D V & 3-D V & 3-D H & $0 \%$ & $5 \%$ & $10 \%$ & $15 \%$ & $20 \%$ \\
\hline 25 & 0.0157 & 0.02 & 0.0094 & 0.00525 & 0.00163 & 0.00193 & 0.00178 & 0.00146 \\
\hline 48 & 0.0156 & 0.0012 & 0.009 & 0.005 & 0.00160 & 0.00191 & 0.00185 & 0.0014 \\
\hline 96 & 0.0122 & 0.0011 & 0.012 & 0.0048 & 0.00154 & 0.00190 & 0.00157 & 0.00139 \\
\hline 190 & 0.0112 & 0.0366 & 0.0065 & 0.0045 & 0.0014 & 0.00187 & 0.00131 & 0.00138 \\
\hline 379 & 0.0111 & 0.003 & 0.0111 & 0.004 & 0.00127 & 0.00184 & 0.0012 & 0.00137 \\
\hline 756 & 0.011 & 0.0028 & 0.011 & 0.0035 & 0.0012 & 0.00148 & 0.0015 & 0.00135 \\
\hline
\end{tabular}

Finally comparing the results of $k$ for field and laboratory contaminated soil samples obtained from permeability falling head method with those obtained from consolidation tests, shows a considerable increase for consolidation results that is most possibly due to applied stresses during consolidation test procedure.

\section{CONCLUSIONS}

In this study the following conclusions have been made,

1. In general, adding oily wastewater to the soil induces a considerable reduction in permeability for both field and laboratory falling head and consolidation methods.

2. Results of permeability obtained from consolidation tests in general have decreased with increasing stresses, for both field and laboratory soil samples.

3 . The $k$ values for laboratory contaminated soil samples that obtained from falling head permeability methods are inverse proportional with the percentages of contamination with oily wastewater, because the first contact of the oil will be with the soil particles which reduces the porosity.
4. The results show that the degree of oily wastewater contamination of the in-situ Kawergosk refinery was between $10 \%-15 \%$.

5. Regarding the results of field permeability test values, for field contaminated soil samples with oily wastewater, the results of 3-D filed permeability, showed that the field clay soil is within the range of low permeable for civil engineering purposes, and within the range of moderate for agricultural and conservation purposes, it can be observed that the effect of oily wastewater on the contamination of existing soil would be seen in long and medium-term periods.

\section{REFERENCE}

Abdul-Resol, H. (1999). Some geotechnical properties of oil contaminated soil. (MSc. Thesis),

Akinwumi, I., Diwa, D., Obianigwe, N., \& Research, E. (2014). Effects of crude oil contamination on the index properties, strength and permeability of lateritic clay. International Journal of Applied Sciences, 3(4), 816-824.

Al-Sanad, H. A., \& Ismael, N. F. (1997). Aging effects on oil-contaminated Kuwaiti sand. 
Journal of geotechnical geoenvironmental engineering, 123(3), 290-293.

ASTM. (D 6391, 2011). Test Method for Field Measurement of Hydraulic Conductivity Using Borehole Infiltration. West Conshohocken, PA: ASTM International.

Aziz, S. Q., \& Fakhrey, E. S. a. (2016). The effect of kawergosk oil refinery wastewater on surrounding water resources. Paper presented at the $1 \mathrm{st}$ International Conference on Engineering and Innovative Technology.

Fine, P., Graber, E., \& Yaron, B. (1997). Soil interactions with petroleum hydrocarbons: abiotic processes. Soil Technology, 10(2), 133153.

Ishibashi, I., \& Harazika, H. (2015). Soil mechanics fundamentals and applications. Boca Raton: CRC Press.

Karkush, M. O., \& Kareem, Z. A. (2017). Investigation of the Impacts of Fuel Oil on the Geotechnical Properties of Cohesive Soil. Engineering Journal, 21(4), 127-137.
Khamehchiyan, M., Hossein Charkhabi, A., \& Tajik, M. (2007). Effects of crude oil contamination on geotechnical properties of clayey and sandy soils. ENGEO Engineering Geology, 89(3), 220-229.

Rahman, Z. A., Hamzah, U., Taha, M. R., Ithnain, N. S., \& Ahmad, N. J. (2010). Influence of oil contamination on geotechnical properties of basaltic residual soil. American Journal of Applied Sciences, 7(7), 954.

Shah, S. J., Shroff, A., Patel, J. V., Tiwari, K., \& Ramakrishnan, D. (2003). Stabilization of fuel oil contaminated soil-A case study. Geotechnical Geological Engineering, 21(4), 415-427.

Ur-Rehman, H., Abduljauwad, S., \& Akram, T. (2007). Geotechnical behavior of oilcontaminated fine-grained soils. Electronic Journal of Geotechnical Engineering, 12(2007).

ferzand.medhat@epu.edu.krd; yousif.mawlood@su.edu.krd 